Acta vet. scand. 1987, 28, 321-332.

From the Department of Pharmacology and Toxicology and Department of Internal Medicine, Norwegian College of Veterinary Medicine, Oslo, Norwegian Defence Research Establishment, Division for Toxicology, Kjeller, and University of Oslo, Anatomical Institute, Norway.

\title{
Neurotoxic Effects of Prenatal Trichlorfon Administration in Pigs
}

\author{
By Gunnar N. Berge, Frode Fonnum \& Per Brodal
}

\begin{abstract}
Berge, G. N., F. Fonnum and P. Brodal: Neutrotoxic effects of prenatal trichlorfon administration in pigs. Acta vet. scand. 1987, 28, 321-332. - Pregnant sows were administered trichlorfon $\left(\right.$ Neguvon $^{\otimes}$ ) during gestation. Examination of the offspring revealed clinical symptoms which included ataxia and tremor. The weights of the cerebrum and the celebellum were significantly reduced $(67 \%$ and $41 \%$ of the control values). There was a clear correlation between the decrease in total brain weight and decrease in cerebellar weight $(r=0.94)$. Histological examination showed a well preserved lamination of the cerebral and cerebellar cortex. Periodical loss of Purkinje cells was the most notable finding in the cerebellum. The molecular layer in such regions was markedly thinned. Neurochemical investigations of the cerebellum showed a significant decrease in specific activity of the transmitter synthesizing enzymes choline acetyltransferase, glutamate decarboxylase and aromatic amino acid decarboxylase $(61.6 \%, 30.3 \%$ and $47.1 \%$ of the control values, respectively). No effect in high affinity D-aspartate uptake was observed.
\end{abstract}

teratogenicity; brain; transmitter enzymes.

\section{Introduction}

The organophosphorus compounds are widely employed in the control of parasites in animal husbandry. The toxicity of these compounds results from their irreversible inhibition of acetylcholinesterase, resulting in the accumulation of acetylcholine at cholinergic sites.

Interest in the possible teratogenic potential of organophosphorus insecticides in mammals was aroused following reports that members of this class of insecticides caused nervous system lesions in chickens (Baron \& Johnson 1964) and also resulted in skeletal abnormalities (Khera 1966, Khera et al. 1967, Greenberg \& La Ham 1969).

Previous studies with trichlorfon in the rat demonstrated teratogenicity when given on days 6 through 15 of gestation only at dose levels that decreased maternal food consumption (Staples \& Goulding 1979). The administration of $360 \mathrm{mg} / \mathrm{kg}$ trichlorfon intraperitoneally in a single dose during gestation in mice caused an embryotoxic effect, but no apparent malformations (Scheufler 1975).

In recent years, however, there have been several case reports that pregnant sows treated with trichlorfon (Neguvon ${ }^{\circledR}$ ) during middle and late period of gestation gave birth to piglets that exhibited nervous disorders, ataxia and a pronounced hypoplasia of the cerebellum (Kronevi 1977, Kronevi \& Bäckstrøm 1977, Kronevi \& Lindquist 1978, Bølske et al. 1978, Knox et al. 1978, Fatzer et al. 1981, Gamlem et al. 1983). Only in the case of Knox et al. 1978 has there been an attempt at a systematic study of the defect. For this rea- 
son there is also controversy in the literature concerning the sensitive period during gestation. The piglets with cerebellar hypoplasia occurred in one case study (Fatzer et al. 1981 ) in litters of sows treated with trichlorfon between days 70 and 75 of gestation. Knox et al. 1978 estimated, however, the sensitive period to be between the 45 th and 63th days of gestation.

Another organophosphorus compound, fenchlorphos, has been tested in reproduction studies in the blue fox (Berge \& Nafstad 1983) and in rabbits (Nafstad et al. 1983). Also these studies emphasized the occurrence of cerebellar hypoplasia among other malformations in the offspring.

The object of the present investigation was to study the cerebellar hypoplasia in piglets following the administration of trichlorfon with histological and neurochemical methods and relate changes to neurotransmitter markers. In the cerebellum the neurotransmitter of the different neurones are fairly well established and data on these systems can therefore be used in characterizing the lesions. In addition, attention was also focused on other changes in the brain which have not been described earlier.

\section{Material and methods Chemical}

The organophosphorus insecticide trichlorfon, dimethyl $(2,2$, 2-trichloro-1-hydroxyethyl) phosphonate, was used as Neguvon ${ }^{\circledR}$ powder produced by Bayer AG, Leverkusen, Federal Republic of Germany. One hundred $\mathrm{g}$ of Neguvon ${ }^{\circledR}$ contained $97 \mathrm{~g}$ of trichlorfon.

\section{Animals and housing}

Three pregnant Norwegian Landrace sows were employed in the experiment. The animals were 1.5-2 years of age and weighed 160,216 and $205 \mathrm{~kg}$ at the time of mating.
They had farrowed 2-3 times with normal litters of sizes before the experiment was conducted.

The sows were housed in separate pens on concrete floor with automatic watering system. They were fed morning and evening with a commercial Norwegian diet for pregnant sows.

\section{Experimental design}

Two sows (A and B) were administered $\mathrm{Ne}$ guvon ${ }^{\circledR}$ orally and 1 sow (C) served as control. To confirm that the parameters recorded from piglets delivered by sow $\mathrm{C}$ were representative, 4 additional piglets selected at random from the litter of 2 different sows were examined.

Since the sensitive period of medication causing cerebellar hypoplasia in the piglets is uncertain, sow A was administered Neguvon ${ }^{\circledR} 4$ times during gestation, at day 71,77 , 87 and 98 of pregnancy. The respective doses were $70,70,35$ and $55 \mathrm{mg} / \mathrm{kg}$. The Neguvon ${ }^{\circledR}$ powder was dissolved in 0.51 of water for a rapid and controlled absorption and given by gavage. No toxic symptoms occurred after the first administration. Hypersalivation, tremor, dyspnoe and weakness of the legs were registered shortly after the second and fourth administration. After the third medication hypersalivation occurred.

To reverse the clinical symptoms after the 2nd and 4th administration, the sow was given $0.1 \mathrm{mg}$ atropin $/ \mathrm{kg}$ subcutaneously about $1 \mathrm{~h}$ after the administration of Neguvon $^{\circledR}$. The experimental details are given in Table 1.

Blood samples for the analysis of acetylcholinesterase were collected from the ear vein before medication and at intervals in connection with the second administration of Neguvon ${ }^{\circledR}$.

Sow B was administered Neguvon ${ }^{\circledR}$ at a dose of $60 \mathrm{mg} / \mathrm{kg}$ twice following the same proce- 
Table 1. Experimental design and reproduction data from sows administered trichlorfon (Neguvon ${ }^{\circledR}$ ) during gestation.

\begin{tabular}{|c|c|c|c|c|c|c|c|}
\hline & $\begin{array}{l}\text { Weight of } \\
\text { the sow } \\
(\mathrm{kg})\end{array}$ & $\begin{array}{c}\text { Age of } \\
\text { the sow } \\
\text { (years) }\end{array}$ & $\begin{array}{l}\text { Number of } \\
\text { earlier } \\
\text { farrowings }\end{array}$ & $\begin{array}{l}\text { Day of gestation/ } \\
\text { Dose of Neguvon }^{\circledast}\end{array}$ & $\begin{array}{l}\text { Duration of } \\
\text { pregnancy } \\
\text { (days) }\end{array}$ & $\begin{array}{l}\text { Number of Number of } \\
\text { live piglets dead piglets }\end{array}$ & $\begin{array}{l}\text { Sex } \\
8 \quad+\end{array}$ \\
\hline Sow A & 216 & 2 & 3 & $\begin{array}{l}\text { 1. Day } 71 .-70 \mathrm{mg} / \mathrm{kg} \\
\text { 2. Day } 77 .-70 \mathrm{mg} / \mathrm{kg} \\
\text { 3. Day } 87 .-35 \mathrm{mg} / \mathrm{kg} \\
\text { 4. Day } 98 .-55 \mathrm{mg} / \mathrm{kg}\end{array}$ & 111 & 12 & 88 \\
\hline Sow B & 205 & $11 / 2$ & 2 & $\begin{array}{l}\text { 1. Day } 77 .-60 \mathrm{mg} / \mathrm{kg} \\
\text { 2. Day } 87 .-60 \mathrm{mg} / \mathrm{kg}\end{array}$ & 115 & $12^{*}$ & 86 \\
\hline $\begin{array}{l}\text { Sow C } \\
\text { (Control) }\end{array}$ & 160 & 2 & 3 & - & 114 & 7 & 45 \\
\hline
\end{tabular}

*Five piglets were saved for use in a later experiment.

dure as sow A on day 77 and day 87 of gestation, respectively. No toxic symptoms were registered and no atropin therefore given. Sow $C$ served as a control and was not medicated.

The litters from the sows were delivered naturally. At term the total number of live and dead piglets were recorded (Table 1). In the period 1-3 days post partum, the piglets were weighed, sexed and sacrificed by $\mathrm{CO}_{2}$ anesthesia and decapitation. Blood samples from the piglets were collected into heparinized tubes. The brain was separated from the spinal cord immediately behind the obex and weighed (Table 2).

The cerebellum was dissected and weighed, and the cerebellum-to-total-brain weight ratio was calculated (Harding et al. 1966). One half of the cerebrum and the cerebellum was immersed in $10 \%$ formalin for histological examination. The other half of the cerebellum was homogenized in cold 0.32 mol sucrose in a glass-Teflon homogenizer for determination of choline acetyltransferase, glutamate decarboxylase, aromatic amino acid decarboxylase and high affinity uptake of $D$ aspartate. The samples for histological exa- mination were embedded in paraffin, sectioned and stained with hematoxylin and eosin.

\section{Enzyme assays}

Four neurochemical parameters, which are used as markers for different transmitter systems, were examined. The neurochemical parameters were either compared per wet weight (specific activities) or compared to the total activity in the cerebellum (sp.activity $\mathrm{x}$ cerebellar wt).

Enzymes were assayed by radiochemical procedures. The tissue homogenate was incubated with the substrate medium in conical micro test-tubes. The labelled substrates, $\left(1-{ }^{-14} \mathrm{C}\right)$ acetylcholine, $\left(1{ }^{-14} \mathrm{C}\right)$ acetylCoA, $\mathrm{L}$ $\left(1-{ }^{14} \mathrm{C}\right)$ glutamatic acid, $\mathrm{D}\left({ }^{3} \mathrm{H}\right)$ aspartic acid and DL-3, 4-dihydroxy $\left(2-{ }^{14} \mathrm{C}\right)$ phenylalanine were purchased from The Radiochemical Centre, Amersham, England.

Acetylcholinesterase (AChE) activity was measured according to the method of Sterri \& Fonnum (1978). Choline acetyltransferase (ChAT) was assayed by the micromethod of Fonnum (1975). Glutamate decarboxylase (GAD) was determined by the method of Albers \& Brady (1959) as modified by Fon- 
num et al. (1977). Aromatic amino acid decarboxylase (AAD) was assayed as described by Broch \& Fonnum (1972). To release maximal enzyme activity before assay all incubation mixtures contained Triton-x-100 (final concentration $0.2 \% \mathrm{v} / \mathrm{v}$ ).

High affinity D-aspartate uptake, a marker of glutamergic terminals, was assayed according to Fonnum et al. (1981). The radioactivity was measured in a Packard Tri-Carb liquidscintillation spectrometer.

\section{Results \\ Acetylcholinesterase (AChE) activity in the sows}

Only a few blood samples of sow A were taken to examine the effect of trichlorfon. Six days after the first dose of trichlorfon, the AChE activity was $71 \%$. Ninety min after the second dose of trichlorfon (i.e. when the sow had clinical symptoms), the AChE activity was recorded to $16 \%$. The activity recovered to $27 \%$ after $24 \mathrm{~h}$ and to $43 \%$ of normal activity after 10 days. The AChE activity 10 days after the third administration of trichlorfon was $53 \%$ of normal activity.

\section{Clinical symptoms and brain examination}

The duration of pregnancy was within normal range. The small number of litters does not allow any extensive conclusions to be drawn on litter size and sex ratio. In a previous study in blue foxes with a related organophosphorus compound, fenchlorphos, we found a dominance of males after treatment during gestation (Berge \& Nafstad 1983).

The clinical symptoms were more pronounced for the delivered piglets from sow A than from sow B. All the piglets in litter A showed nervous symptoms which were characterized by severe ataxia and tremor. Many of the piglets were not able to stand. Incoordinated movements were most pronounced for the hindlimbs, but were also registered in the forelimbs. One piglet had an abnormal head position and moved in circles. No sucking reflex was observed.

In litter B, however, the clinical symptoms were less severe. A slight tremor was registered in a few piglets and only when moving. These piglets showed a tendency to incoordination of the hindlimbs, especially when standing.

A more dramatic effect on the brain weights was found for litter A, treated 4 times, compared to litter B, treated only twice.

The most severe effect of trichlorfon administration was observed on the cerebellum. The size was considerable reduced with indistinct foliation. In litters A and B, the average weights of the cerebella were calculated to be $41 \%$ and $61 \%$ of the controls, respectively. In our further analyses of the individual data we have therefore correlated the individual changes with the changes in the cerebellum weight.

There was a poor correlation between cerebellum weight and body weight $(r=0.64)$ although the animals with the smallest cerebellum also showed largest decrease in the body weight (Fig. 1).

The results indicated a significant decrease not only in the cerebellum weight, but also in

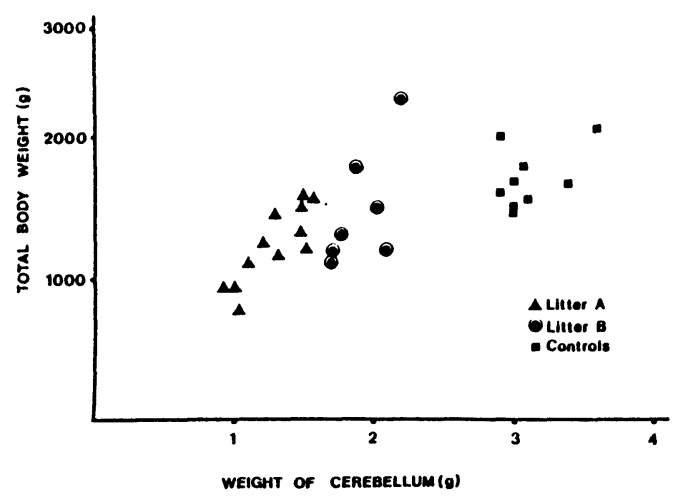

Figure 1. Comparison between cerebellum and body weight in piglets born by sows administered trichlorfon (Neguvon ${ }^{\circledR}$ ) during gestation. 
Table 2. Observations on piglets born by sows administered trichlorfon (Neguvon ${ }^{\circledR}$ ) during gestation.

\begin{tabular}{lcccccc}
\hline & $\begin{array}{c}\text { Number of } \\
\text { piglets } \\
(\mathrm{n})\end{array}$ & $\begin{array}{c}\text { Weight of } \\
\text { the piglets } \\
(\mathrm{g})\end{array}$ & $\begin{array}{c}\text { Total } \\
\text { brain } \\
\text { weight }(\mathrm{g})\end{array}$ & $\begin{array}{c}\text { Weight of } \\
\text { cerebellum } \\
(\mathrm{g})\end{array}$ & $\begin{array}{c}\text { Cerebellum/ } \\
\text { total brain } \\
\text { ratio (\%) }\end{array}$ & $\begin{array}{c}\text { Cerebellum/ } \\
\text { total body } \\
\text { weight ratio (\%) }\end{array}$ \\
\hline Litter A & 12 & $1273^{* *}$ & $20.98^{*}$ & $1.29^{*}$ & $4.10^{\mathrm{a}}$ & \\
& & \pm 294 & \pm 1.82 & \pm 0.22 & $(6.15)$ & 0.10 \\
\hline Litter B & 7 & 1479 & $25.34^{*}$ & $1.92^{*}$ & $6.08^{\mathrm{a}}$ & \\
& & \pm 414 & \pm 1.42 & \pm 0.20 & $(7.56)$ & 0.13 \\
\hline Litter C & $9 \mathrm{~b}$ & 1694 & 31.53 & 3.13 & 9.93 & 0.18 \\
(Control) & & \pm 221 & \pm 1.54 & \pm 0.26 & & \\
\hline
\end{tabular}

The weight are presented as mean $\pm \mathrm{SD}$.

aCalculated from the total brain-weight of the controls

bIncluding 2 dead piglets

$*<0.001$

$* *<0.05$

the total brain weight (Table 2). More detailed studies (Fig. 2) show that there was a clear correlation between the decrease in total brain weight and the decrease in cerebellar weight $(r=0.94)$. The decrease in total brain weight was $33 \%$ for the piglets in litter $A$ and $20 \%$ in litter $B$, which is less than the decrease for the cerebellum weight.

In a few animals several brain regions were dissected and weighed and there was a clear

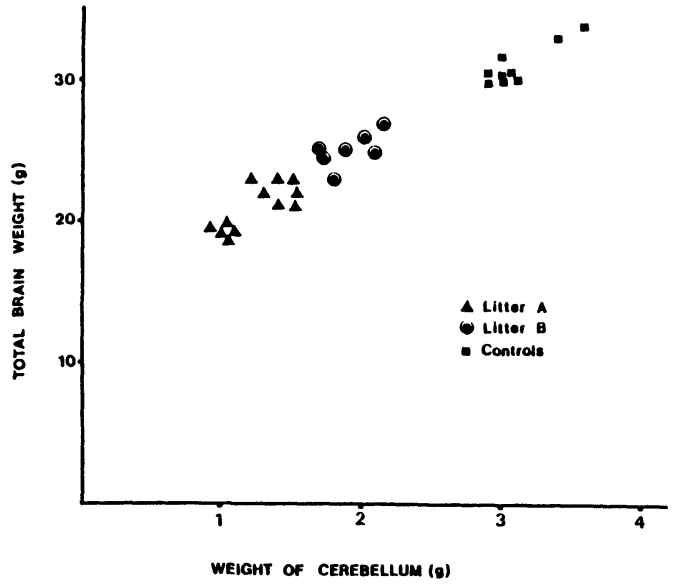

Figure 2. Comparison betwen cerebellum and total-brain weight in piglets born by sows administered trichlorfon (Neguvon ${ }^{\circledR}$ ) during gestation. difference in weight in all the regions examined (Table 3). The decrease in cerebrum is illustrated in Fig. 3.

\section{Acetylcholinesterase in piglet erythrocytes}

Erythrocytes from piglets born by sow A were examined at birth (i.e. 13 days after the last trichlorfon treatment). The correlation coefficient between AChE activity and cerebellum weight was 0.67 and indicated a poor correlation. The average AChE activity was $55 \%$ of the activity measured in the unhibited controls $(\mathrm{p}<0.001)$.

\section{Neurochemical investigations}

Choline acetyltransferase (ChAT), a marker for the cholinergic neurons, showed a significant decrease for litter A, the most affected animals. When we compared the total ChAT activity in cerebellum, the activities in litter $A$ and $B$ were reduced to $15.8 \%$ and $51.9 \%$ of the control values, respectively.

Glutamate decarboxylase (GAD), a marker for GABA'ergic neurons, also showed a significant decrease in specific activity in litter A. The decrease was, however, less marked than the specific activity of ChAT. There 
Table 3. Weights of selected regions of the brain in piglets (litter A) born by sow administered trichlorfon (Neguvon ${ }^{\circledR}$ ) during gestation.

\begin{tabular}{lcccc}
\hline & $\begin{array}{c}\text { Cortex } \\
(\mathrm{g})\end{array}$ & $\begin{array}{c}\text { Hippocampus } \\
(\mathrm{g})\end{array}$ & $\begin{array}{c}\text { Colliculus } \\
\text { sup. et inf. } \\
(\mathrm{g})\end{array}$ & $\begin{array}{c}\text { Medulla } \\
\text { oblongata } \\
(\mathrm{g})\end{array}$ \\
\hline Control & 10.09 & 0.52 & 0.64 & 1.03 \\
& \pm 1.42 & \pm 0.06 & 0.70 & 1.04 \\
\hline Litter A & 6.00 & 0.36 & 0.35 & 0.71 \\
& 7.10 & 0.35 & 0.45 & 0.76 \\
\hline
\end{tabular}

was no decrease of GAD in litter B. The total GAD activity was, however, significantly reduced for both litter A and B to $28.8 \%$ and $65.6 \%$ of the control values, respectively. Aromatic amino acid decarboxylase (AAD), a marker for the biogenic amines, both serotonin and noradrenalin, showed a significant decrease also for litter B. Unfortunately the values are not available for litter $A$. The total activity of AAD in litter $\mathrm{B}$ was reduced to $32.3 \%$ of the control values.

High affinity uptake of D-aspartate is a marker for glutamergic neurons. For this parameter there was no significant decrease in any of the treated litters. The total activity was therefore reduced to the same extent as cerebellum.

\section{Histological observations}

The cerebral cortex was somewhat thinner in treated animals than in the controls when corresponding regions from the frontal and occipital lobes were examined. Otherwise, the laminar organization was undisturbed and there were no signs of degenerative or inflammatory processes.

The cerebellar cortex (Fig. 4) also had a preserved lamination in the experimental piglets, and appeared in most places to be normal although it was generally thinner than in the controls. However, on closer examination, there was a conspicuous lack of Purkinje cells in some areas. This occurred mainly in small regions, where 2-10 Purkinje cells in a row might be "absent" (Fig. 4C).

Figure 4. Photomicrographs from sagittal paraffin sections of the cerebellum of piglets born by sows administered trichlorfon (Neguvon ${ }^{\circledR}$ ) orally during gestation. Hematoxylin and eosin staining. A-D from experimental animals; E-H from normal controls.

A. A severely affected region on the top of three folia is interspaced between more normal regions. Particularly the molecular layer (mo.) is markedly thinned. Compare with $\mathrm{E}$ from normal control (same magnification as in A).

B. Higher magnification from a severely affected region. Such regions make upon only a small fraction of each cerebellar section. Note that the external granular layer (e.gr.) is almost absent, very few Purkinje cells are found and the granular layer ( $\mathrm{gr}$.) is very cell-poor.

C. Less severely affected cerebellar cortex, with absence of Purkinje cells to the left in the folium, but otherwise well preserved external granular-, molecular- and granular layers.

D. From a region without any clearcut abnormalities, except that the cortex is thinner than in controls (compare with $F$ and $G$, same magnification).

$\mathrm{G}$ and $\mathrm{H}$. Smaller regions with lack of Purkinje cells $(\mathrm{G})$ and thinning of the molecular layer $(\mathrm{H})$ are found also in the normal controls. 
Gunnar N. Berge, Frode Fonnum and Per Brodal: Neurotoxic effects of prenatal trichlorfon administration in pigs.
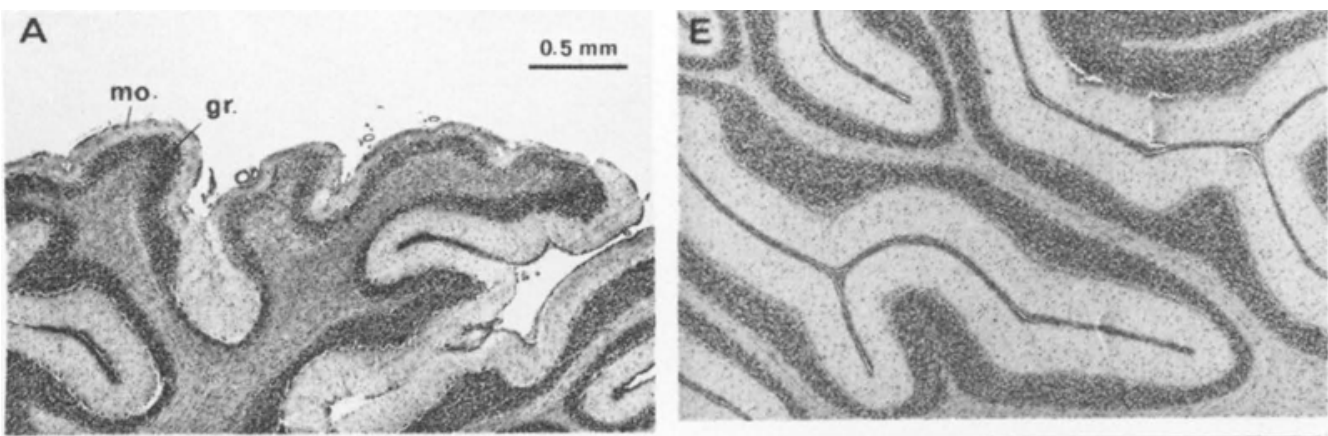

B
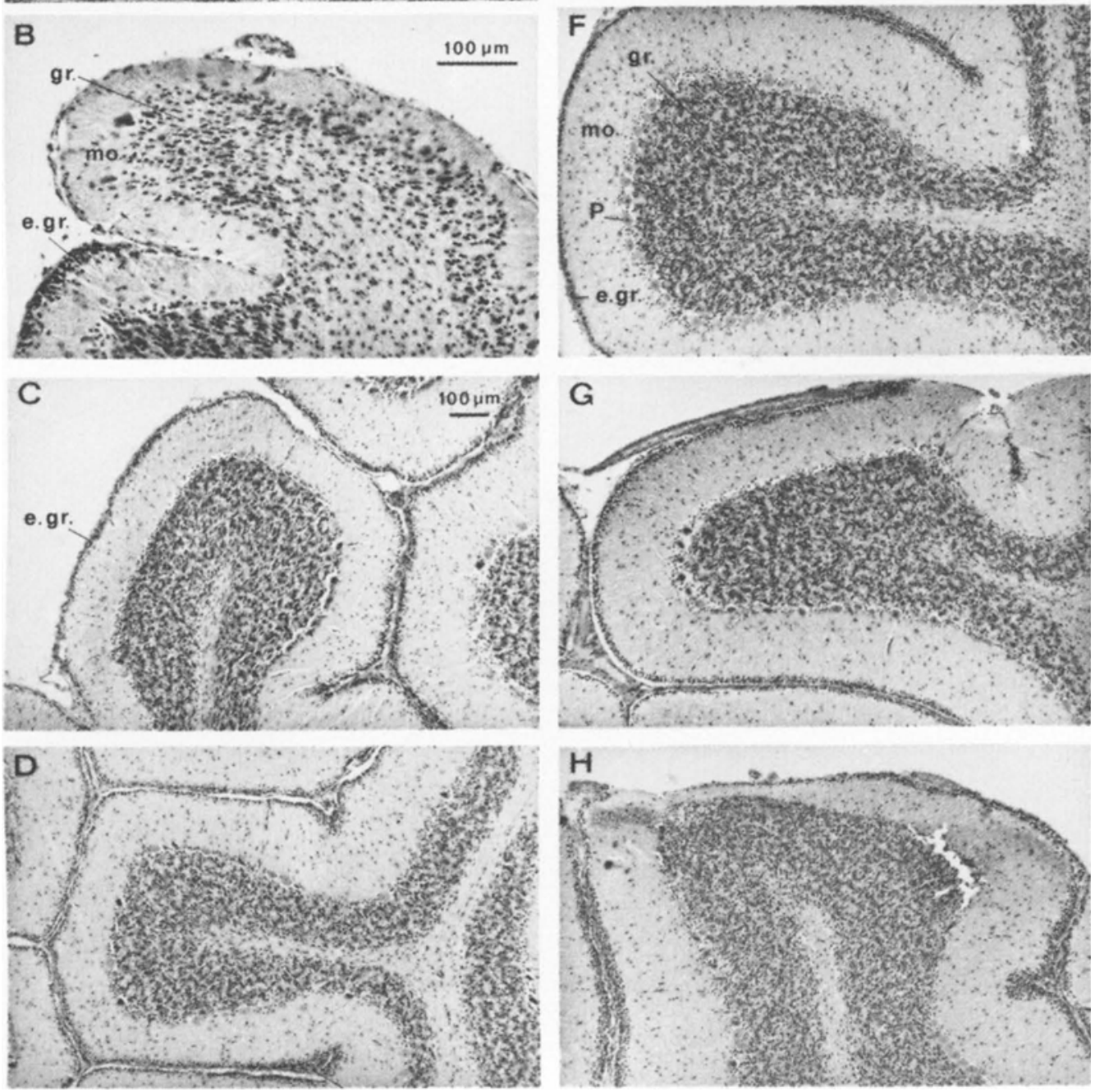



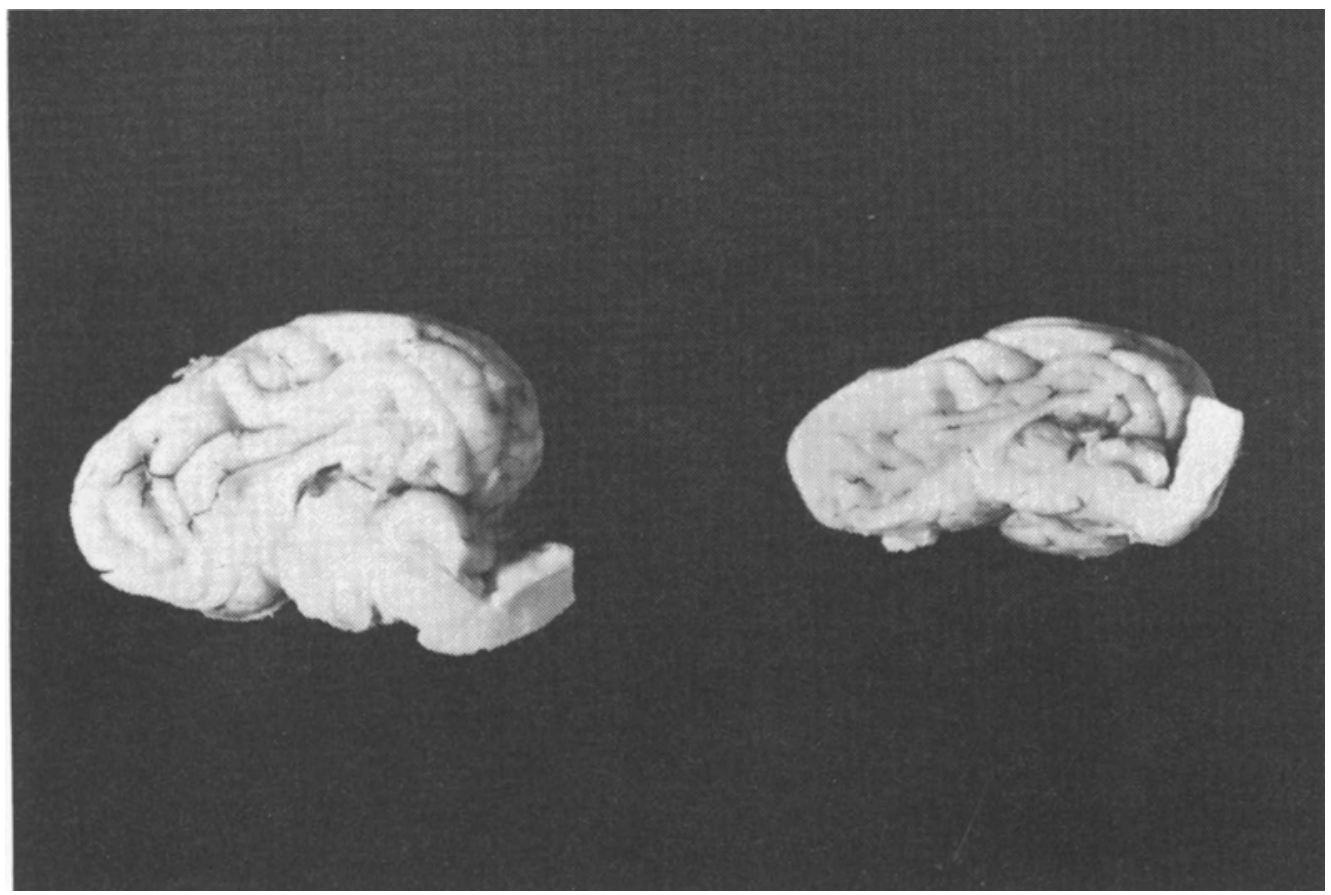

Figure 3. Brain (without cerebellum) of piglet born by sow administered trichlorfon (Neguvon ${ }^{\circledR}$ ) during gestation (right) compared to control (left).

Table 4. Various transmitter-related parameters in the cerebellum of piglets born by sows administered trichlorfon (Neguvon ${ }^{\otimes}$ ) during gestation.

\begin{tabular}{lcccc}
\hline \multicolumn{5}{c}{ Concentrations (nmol/h/g wet wt.) } \\
\hline $\begin{array}{c}\text { Choline } \\
\text { acetyl- } \\
\text { transferase }\end{array}$ & $\begin{array}{c}\text { Glutamate } \\
\text { decarboxy- } \\
\text { lase }\end{array}$ & $\begin{array}{c}\text { Aromatic } \\
\text { amino acid } \\
\text { decarboxylase }\end{array}$ & $\begin{array}{c}\text { High affinity } \\
\text { D-aspartate } \\
\text { uptake }\end{array}$ \\
\hline $\begin{array}{l}\text { Control } \\
(\mathrm{n}=7)\end{array}$ & $224 \pm 38$ & $8770 \pm 508$ & $17 \pm 5$ & $55 \pm 12$ \\
\hline $\begin{array}{l}\text { Litter A } \\
(\mathrm{n}=8)\end{array}$ & $86 \pm 6^{*}$ & $6116 \pm 334^{*}$ & - & $53 \pm 12$ \\
\hline $\begin{array}{l}\text { Litter B } \\
(\mathrm{n}=5)\end{array}$ & $190 \pm 55$ & $9413 \pm 247$ & $9 \pm 2^{*}$ & $47 \pm 4$ \\
\hline
\end{tabular}

Values presented as mean \pm SD

${ }^{*} \mathrm{p}<0.001$ 
The granular and molecular layers were as a rule well preserved in such regions, but sometimes the molecular layer was markedly thin (Fig. 4A and B). The relatively severe changes shown in Fig. 4A-B were, however, found only occasionally and it should be stressed that even in the control cerebella, "empty spaces « in the Purkinje cell layer were frequently seen (Fig. 4G). It appeared, however, that this occurred in more places and that more Purkinje cells in a row were lacking in the experimental animals. Nevertheless, a quantitative study is necessary to further elucidate the significance of this apparent loss of Purkinje cells.

\section{Discussion}

We have in the present study demonstrated that the organophosphorus compound trichlorfon, when given to sows during gestation, is able to produce cerebral hypoplasia in newborn piglets in addition to the cerebellar hypoplasia previously observed. The defect has been characterized by neurochemical and histological methods. The most important neurochemical findings in the cerebellum were the decrease in the transmitter synthesizing enzymes ChAT, GAD and AAD. The most significant histological changes observed were the periodical losses of Purkinje cells. However, in spite of the large reduction in brain weights, the histological observations were characterized by a well preserved lamination of the cerebellum and cerebrum.

Previous investigations (Kronevi et al. 1975, Kronevi \& Bäckstrøm 1977, Bølske et al. 1978, Knox et al. 1978) of piglets born by trichlorfon-treated sows were based on changes in the cerebellar/total brain ratio calculaed according to Harding et al. (1966). The findings in our experiment of a simultaneous loss in total-brain weight questions, however, the value of this parameter. Corre- lated to a normally by developed brain's weight $(31.53 \mathrm{~g})$, the ratio was 0.10 for normal cerebellum and 0.04 and 0.06 for litter $A$ and $B$, respectiveiy. The reduced weight of the whole brain has not been reported by other investigators. By an inspection of the previous data (Kronevi et al. 1975, Kronevi \& Bäckstrøm 1977, Bølske et al. 1978) there were significant variations in the total-brain weight ranging from about $25 \mathrm{~g}$ to $35 \mathrm{~g}$. Our examination indicated that most brain regions were probably affected (Table 3 ).

It is known that the susceptibility to teratogenic agents varies with the developmental stage at the time of exposure. The critical period of sensitivity to teratogens for pigs, ranges from 12-34th day of gestation (Schardein 1976). The cerebellar hypoplasia is produced much later, although the exact time is controversial. Knox et al. (1978) estimated from breeding data the sensitive period for cerebellum to be between day 45 and 63 of gestation. However, from their data of the experimental part of the report, it is apparent that administration of trichlorfon even up to day 70 had an effect. In a later investigation (Fatzer et al. 1981), congenital ataxia, tremor and cerebellar hypoplasia occurred only after administration in the period between day 70 and 75 of gestation. When trichlorfon was given earlier in pregnancy, i.e. 34-41 and 56-63 days of gestation, severe clinical symptoms but no hypoplasia of the cerebellum were observed. No data were, however, presented on cerebellar and cerebral weights.

In the present experiment we have produced significant cerebellar hypoplasia in piglets born by sows treated for the first time at day 71 and even as late as day 77 . We therefore assume that the cerebellar hypoplasia may be produced over a period of at least from day 45 to day 77 of gestation.

Davison \& Dobbing (1966) suggested that 
the vulnerability of the growing brain is related to the timing and velocity of its maximum growth rate, known as the brain growth spurt. This is a transient period during which increase in brain weight and a number of other important developmental processes proceed at a very high velocity. Interference during this period may lead to irreversible distortions and deficits in the adult brain.

Dickerson \& Dobbing (1967) found that in pigs the maximum growth rate for the whole brain extends from about 6 weeks before birth to about 5 weeks afterwards. The cerebellum, however, showed a faster growth rate than the total brain during this period with its peak value around birth (Dickerson \& Dobbing 1967, Done \& Herbert 1968). This rapid growth in the cerebellum could indicate higher vulnerability to developmental disturbance, in agreement with our investigation.

In previous reports concerning prenatal exposure to different organophosphorus compounds, decreased body weight of the newborn was found to be a sensitive indicator of toxic effect (Kimbrough \& Gaines 1968, Budreau \& Singh 1973). The present investigation showed a significantly reduced body weight for litter A, but not for litter B. However, the wet weight of the brain at term is relatively constant under normal conditions, in spite of considerable variations in total body weight (Robinson \& Tigard 1966).

It should be noted that the appearance and growth of various cerebellar cell types seem to occur at a specific time for each cell type. In the present morphological investigation, the patchy loss of Purkinje cells was the most notable finding. There seems to be no data available in the literature on the development of the Purkinje cells in pigs. However, it is known that in the mouse the Purkinje cells of the cerebellum are established by a burst of activity that lasts only 2 or 3 days (Rodier 1980). Since the effect on the cerebellum obviously can be obtained over an extensive period of several days (even weeks) in the pig, it seems less likely that the toxic effect is linked to the »birth « of the Purkinje cells only. We cannot, however, exclude the possibility that trichlorfon may be particularly toxic to the Purkinje cells during their development and cause their disintegration. Since the Purkinje cells are the first cell group to be established in the cerebellum (Rodier 1980), their subsequent loss may limit the development of other cerebellar neurons.

Within the cerebellar cortex there are 5 types of neurons. Four of these are definitely inhibitory, namely the Purkinje cells, Golgi cells, basket cells and stellate cells. Previous studies using a histochemical stain for glutamic acid decarboxylase suggested that GABA is a neurotransmitter for all these inhibitory cells in the cerebellum (Saito et al. 1974). Glutamate decarboxylase measurement in the present study indicated that the GABA-ergic system decreased slightly more than the cerebellar weight. This finding indicates a moderate loss of GABA-ergic structures in the cerebellum, but does not allow us to conclude as to which struture is decreased.

Lesion studies from cerebellum have demonstrated that all cholinergic fibres in the cerebellum enter throug the peduncles (Fonnum 1972). The cholinergic fibres are partly mossy fibres (Kasa \& Silver 1969). AAD is localized to the small thin fibres entering the cerebellum from the locus coeruleus and the raphe nuclei (Schulman 1983). It has been suggested that both acetylcholine and biogenic amines have a function as stissue organizers« in embryonic tissues prior to their adult role as neurotransmitters (Byron 1975). Their role in the development of the 
autonomic nervous system has been the subject of many reviews (Black 1978, Bunge et al. 1978, Marx 1979). The ChAT and AAD systems may therefore be the primary target. The lesion caused by this event may be involved in the impaired development of the cerebellum. Alternatively, cholinergic and aminergic fibres may degenerate as a secondary effect to the injury of other cerebellar structures. We cannot, at present, differentiate between these two alternatives. It is interesting that the two most affected transmitter enzymes are markers for fibres entering cerebellum.

We have not yet been able to elucidate the mechanism for the cerebellar and cerebral hypoplasia, but several possibilities exist which will warrant further investigation. The toxic effect of trichlorfon may be directed either towards specific cell structures such as the Purkinje cells, or cell fibres such as the cholinergic and aminergic ones, which may possess tissue organizing functions. Furthermore, earlier investigations have indicated the existence of a »cholinergic « system in the placenta (Sastry \& Henderson 1972, Sastry et al. 1973), which probably is involved in transport processes (Harbison et al. 1975). Pesticides of the organophosphorus series may therefore alter the function of the placental cholinergic system by influencing the levels of acetylcholine and subsequently the fetal growth and development. The toxic effect of trichlorfon may result in a decreased nutritional uptake to the brain during the growth spurt period, which is known to produce a general non-specific reduction in brain tissues with a more severe effect on the cerebellum than on the rest of the brain (Dobbing 1972).

\section{Acknowledgement}

The authors wish to express their sincere thanks to professor Erling Søgnen and professor Inger Nafstad for useful help, valuable advice and comments. The technical assistance of Mrs. E. Iversen, Mrs. Sidsel Sohlberg and Mr. T. Myrvold is greatly appreciated. This work was supported by grants from the Norwegian Agricultural Research Council.

\section{Reference}

Albers $R W$, Brady $R O$ : The distribution of glutamate decarboxylase in the nervous system of the rhesus monkey. J. Biol. Chem. 1959, 234, 926928.

Baron $R$ L, Johnson H: Neurological disruption produced in hens by two organophosphate esters. Brit. J. Pharmacol. 1964, 23, 295-304.

Berge $G N$, Nafstad I: Teratogenicity and embryotoxicity of orally administered fenchlorphos in blue foxes. Acta vet. scand. 1983, 24, 99-112.

Black I R: Regulation of autonomic development. Annu. Rev. Neurosci. 1978, 1, 183-214.

Broch $O J$, Fonnum $F$ : The regional and subcellular distribution of catechol-O-methyl-transferase in the rat brain. J. Neurochem. 1972, 19, 2049 2055.

Budreau $C H$, Singh $R$ P: Teratogenicity and embryotoxicity of demeton and fenthion in CF \# 1 mouse embryos. Toxicol. Appl. Pharmacol. 1973, 24, 324-332.

Bunge R, Johnson $M$, Ross C D: Nature and narture in development of the autonomic neuron. Science 1978, 199, 1409-1416.

Byron J W: Manipulation of the cell cycle of the hemopoietic stem cell. Exp. Hematol. 1975, 3, 4453.

Bølske G, Kronevi T, Lindgren NO: Congenital tremor in pigs in Sweden. Nord. Vet. Med. 1978, 30, 534-537.

Davison A N, Dobbing J: Myelination as a vulnerable period in brain development. Brit. Med. Bull. 1966, 22, 40-44.

Dickerson J WT, Dobbing J: Prenatal and postnatal growth and development of the central nervous system of the pig. Proc. Roy. Soc. B. 1967, 166, 384-395.

Dobbing J: Vulnerable periods of brain development. In: CIBA Foundation Symposia. Lipids, Malnutrition \& the Developing Brain. Elsevier, Amsterdam 1972, p. 9-20.

Done J T, Hebert N: The growth of the cerebellum in the foetal pig. Res. Vet. Sci. 1968, 9, 143-148. 
Fatzer R, Häni H, Scholl E: Ko..genitaler Tremor und zerebelläre Hypoplasie bei Ferkeln nach Behandlung der Mutterschweine mit Neguvon ${ }^{\otimes}$ während der Trächtigkeit. (Congenital tremor and cerebellar hypoplasia in piglets following trichlorfon treatment of pregnant sows). Schweiz. Arc. Tierheil. 198', 12, 29-36.

Fonnum F: Localization of cholinergic and y-aminobutyric acid containing pathways in brain. In: Metabolic Compartmentation in the Brain, ed. R. Balázs and J. E. Cremer. The Macmillan Press Ltd. 1972, p. 245-257.

Fonnum F: A rapid radiochemical method for the determination of choline acetyltransferase. J. Neurochem. 1975, 25, 407-409.

Fonnum $F$, Walaas I, Iversen E: Localization of GABAergic, cholinergic and aminergic structures on the mesolimbic system. J. Neurochem. 1977, 29, 221-230.

Fonnum F, Storm-Mathisen J, Divac I: Biochemical evidence for glutamate as neurotransmitter in corticostriatal and corticothalamic fibres in rat brain. Neuroscience 1981, 6, 863-873.

Gamlem H N, Lund A, Moen J H, Berge G N: Kongenital tremor og cerebellum-hypoplasi hos spedgriser som en mulig følge av Neguvon ${ }^{\circledR}$-behandling av drektige purker. (Congenital tremor and cerebellar hypoplasia in piglets associated with trichlorfon-treatment of pregnant sows). II. En kasuistisk meddelelse. Norsk Vet. tidssk. 1983, 6, 385-387.

Greenberg J, La Ham $Q N$ : Malathion induced teratism in the developing chick. Can. J. Zool. 1969, 47, 539-542.

Harbison $R D$, Olubadewo J, Dwivedi $C$, Sastry $B V$ $R$ : Proposed role of the placental cholinergic system in the regulation of fetal growth and development. In: Basic and Therapeutic Aspects of Perinatal Pharmacology, ed. P. L. Morselli, S. Garattini and F. Sereni, Raven Press, New York, 1975, p. 107-120.

Harding J D J, Done J T, Darbyshire J H: Congenital tremor in piglets and their relation to swine fever. Vet. Rec. 1966, 79, 388-389.

Kàsa $P$, Silver A: The correlation between choline acetyltransferase and acetylcholinesterase activity in different areas of the cerebellum of rat and guinea pig. J. Neurochem. 1969, 16, 389-396.
Khera $K S$ : Toxic and teratogenic effects of insecticides in duck and chick embryos. Toxicol. Appl. Pharmacol. 1966, 8, 345.

Khera $K S$, La Ham $Q N$, Ellis $C F$, Zawidzka Z Z, Grice $C H$ : Foot deformity in duck from injection of EPN during embryogenesis. Toxicol. Appl. Pharmacol. 1967, 8, 540-549.

Kimbrough $R$ D, Gaines $T$ B: Effect on organic phosphorus compounds and alkylating agents on the rat fetus. Arch. Environ. Health 1968, 16, 805-808.

Knox B, Askaa J, Basse A, Bitsch V, Eskildsen M, Mandrup M, Ottosen HE, Øverby E, Pedersen $K$ $B$, Rasmussen $F$ : Congenital ataxia and tremor with cerebellar hypoplasia in piglets born by sows treated with Neguvon ${ }^{\otimes}$ vet. during pregnancy. Nord. Vet. Med. 1978, 30, 538-545.

Kronevi T: Kan Neguvon ${ }^{\circledR}$-behandling av dräktiga suggor orsaka cerebellär hypoplasi hos gris? (Can Neguvon ${ }^{\otimes}$-treatment of pregnant sows cause cerebellar hypoplasia in piglets?) Svensk Vet. tid. 1977, 29, 931-932.

Kronevi T, Bäckström L: Kongenital tremor (skaksjuke) hos gris (Congenital tremor in piglets). Svensk Vet. tid. 1977, 29, 837-841.

Kronevi T, Hansen H J, Jonsson O J: Cerebellar hypoplasia of unknown etiology in pigs. Vet. Rec. 1975, 96, 403-404.

Kronevi T, Lindquist $\mathrm{J} O$ : Mera om kongenital tremor (skaksjuke) hos gris. (More about congenital tremor in pigs. Case report). Svensk Vet. tid. 1978, 30, 415-416.

Marx $J L$ : New information about the development of the autonomic nervous system. Science 1979, 206, 434-437.

Nafstad I, Berge G, Sannes E, Lyngset A: Teratogenic effects of the organophophorus compound fenchlorphos in rabbits. Acta vet. scand. 1983, 24, 295-304.

Robinson R J, Tigard J P M: Central nervous system in the new born. Brit. Med. Bull. 1966, 22, 49-55.

Rodier P M: Chronology of neuron development: Animal studies and their clinical implications. Develop. med. Child Neurol. 1980, 22, 525-545.

Saito K, Barber R, Wu J, Matsuda T, Roberts E, Vaughn $J E$ : Immunohistochemical localization of glutamate decarboxylase in rat cerebellum. Proc. Natl. Acad. Sci. 1974, 71, 269-273. 
Sastry $B V R$, Henderson $G I$ : Kinetic mechanisms of human placental choline acetyltransferase. Biochem. Pharmacol. 1972, 21, 787-802.

Sastry B V R, Olubadewo J, Smidt D E: Placental cholinergic system and occurrence of acetylcholine in placenta. Fed. Proc. 1973, 32, 742.

Schardein $J L$ : Drugs as teratogens. CRC Press, Inc., Ohio, USA 1976, 17.

Scheufler H: Der Einfluss relativ hoher Dosen von Dimethoat and Trichlorphon auf die Keimesentwicklung der Labormaus. (Influence of relatively high dosis of dimethoat and trichlorfon on the embryonal development of the mouse). Biologische Rundschau 1975, 13, 238-240.

Schulman $J A$ : Chemical neuroanatomy of the cerebellar cortex. In: Chemical Neuroanatomy, ed. P. C. Emson, Raven Press, New York 1983, p. 209-228.

Staples $R E$, Goulding $E H$ : Dipterex teratogenicity in the rat, hamster and mouse when given by gavage. Environm. Health Perspec. 1979, 30, 105113.

Sterri $S$ H, Fonnum F: Isolation of organic anions by extraction with liquid anion exchangers and its application to micromethods for acethylcholinesterase and 4-aminobutyrate aminotransferase. Eur. J. Biochem. 1978, 91, 215-222.

\section{Sammendrag}

Nevrotoksiske effekter forårsaket av prenatal administrasjon av triklorfon til gris.

Drektive purker ble gitt triklorfon (Neguvon ${ }^{\circledR}$ ) oralt på dag 71, 77, 87 og 98 etter bedekning. Grisungene viste symptomer som ataksi og tremor. Vektene av cerebrum og cerebellum var signifikant redusert og utgjorde henholdsvis $67 \%$ og $41 \%$ av kontrolldyrene. Det var klar korrelasjon mellom reduksjonen i total hjernevekt og reduksjonen i vekten av cerebellum $(r=0.94)$. Histologiske undersøkelser viste en tydelig laminering av cortex både $i$ cerebrum og cerebellum. Stedvis tap av Purkinje celler ble observert $i$ cerebellum.

Nevrokjemiske undersøkelser av cerebellum viste signifikant reduksjon i aktiviteten av de transmittor syntetiserende enzymene kolin acetyltransferase, glutamat dekarboksylase og aromatisk aminosyre dekarboksylase (henholdsvis $30,4 \%, 69,7 \%$ og $52,9 \%$ av kontrollverdiene). Ingen effekt på høy affinitet $\mathrm{D}$-aspartat opptak ble observert.

(Received March 16, 1987).

Reprints may be requested from: G. N. Berge, Department of Pharmacology and Toxicology, Norwegian College of Veterinary Medicine, P. O. Box 8146, Dep. N-0033 Oslo 1, Norway. 